\title{
Argentinien als Absatzgebiet der Eisenbahnbedarfsindustrie
}

voll

Dr. rer. pol. Bernhard Stichel.

HAMBURG 1916. 
Alle Rechte vorbehalten.

Druck von Lütcke \& Wulff, Hamburg. 